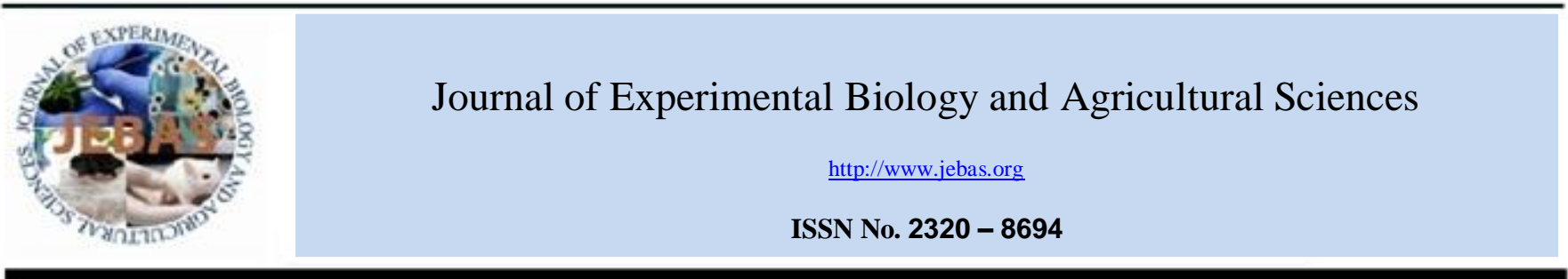

\title{
SCREENING OF FUNGAL ENDOPHYTES ISOLATED FROM MEDICINAL PLANTS FOR GLUTAMINASE FREE L-ASPARAGINASE ACTIVITY
}

\author{
Hemlata Bhosale, Amani Esmaeil As-Suhbani*
}

DST-Fist Sponsored School of Life Sciences, Swami Ramanand Teerth Marathwada University, Nanded, M. S., India 431606.

Received - May 15, 2019; Revision - June 29, 2019; Accepted - July 20, 2019

Available Online - August 05, 2019

DOI: http://dx.doi.org/10.18006/2019.7(4).396.402

\section{KEYWORDS \\ Fungal Endophytes \\ Medicinal plants \\ L-asparaginase \\ Fusarium solani \\ Therapeutic index}

\begin{abstract}
Endophytes considered as a potent source of naturally produced bioactive compounds. This study was designed to isolate fungal endophytes that are capable of producing Glutaminase free L-asparaginase enzyme from the selected medicinal plants of Nanded city, Maharashtra, India. Four host medicinal plants traditionally known to have antitumour properties, i.e., Curcuma longa, Murraya koenigii, catharanthus roseus and Withania somnifera were selected for this study. Among the total seventy eight (78) isolated fungal endophytes, only five isolates were shown Glutaminase free L-asparaginase production activity. Fusarium solani isolated from Curcuma longa showed the highest enzyme production activity level as compared to others by $619.102 \mathrm{IU} \mathrm{ml}^{-1}$ with $8.807 \mathrm{IU} \mathrm{mg}^{-1}$ specific activity, followed by F.oxysporum (514.532 $\mathrm{IU} \mathrm{ml}^{-1}$ with $7.401 \mathrm{IU} \mathrm{mg}^{-1}$ specefic activity), Penicillium sp. (307.114 $\mathrm{IU} \mathrm{ml}^{-1}$ with $5.033 \mathrm{IU} \mathrm{mg}^{-1}$ specific activity), Aspergillus sp. (216.847 $\mathrm{IU} \mathrm{ml}^{-1}$ with 4.920 specific activity ) and Alternaria sp. (149.057 $\mathrm{IU} \mathrm{ml}^{-1}$ with $3.035 \mathrm{IU} \mathrm{mg}^{-1}$ specific activity). This study demonstrate the importance of using fungal endophytes from antitumour plant hosts as a good and potent alternative source for L-asparaginase production with novel characteristics at high therapeutic index.
\end{abstract}

* Corresponding author

E-mail: amaniesmaeil.7@gmail.com (Amani Esmaeil As-Suhbani)

Peer review under responsibility of Journal of Experimental Biology and Agricultural Sciences.

Production and Hosting by Horizon Publisher India [HPI] (http://www.horizonpublisherindia.in/).

All rights reserved.
All the articles published by Journal of Experimental Biology and Agricultural Sciences are licensed under a Creative Commons Attribution-NonCommercial 4.0 International License Based on a work at www.jebas.org.

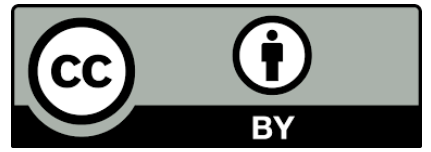




\section{Introduction}

Medicinal plants have been utilized and recognizes all through mankind's history. Natural products of medicinal plants are usually used in preparation of cosmetics, pharmaceutical drugs, insecticides, pesticides, and fertilizers (Manasa \& Nalini, 2014). Since two decades following the discovering of taxol-producing fungal endophyte Taxomyces andreanae, researchers have concentrated on the endophytes; microbes living within the healthy tissues of plants; as alternatives in the production of the valued metabolites (Stierle et al., 1993).

Endophytes are microorganisms including fungi, bacteria and actinomycetes which reside in the internal tissue of plants for all or parts of its life cycle. Endophytes have capability of colonizing in the internal tissues of healthy plant's leaves, stems, bark, root, twigs, flower, seeds and fruit without causing any obvious harmful effect or pathogenic infection to the host plants. Endophytes considered valuable because of their ability to synthesize various important bioactive compounds. These bioactive compounds were basically involved in defence mechanisms of plants against plant pathogens (Fouda et al., 2015; Chow \& Ting, 2015).

L-asparaginase enzyme (L-asparagine amidohydrolase, E.C. 3.5.1.1.) is well accepted as an antitumour agent used in combination therapy with other drugs in the therapy of some lymphomas and leukemias (Jha et al., 2012;Arjun et al., 2015; ElNaggar et al., 2015). It has been used for more than 30 years in the treatment of acute lymphoblastic leukemia (ALL) (Ghasemi et al., 2017). It acts as catalyzing agent for the conversion of amino acid L-asparagine to ammonia and L-aspartatic acid (Arif \& Hussain, 2014; Kavya \& Madhu, 2019). This hydrolysis process generally occurred in two steps through an inter-mediate product: beta-acyl-enzyme (Figure 1). In first step, a strong base activates the enzyme nucleophilic residue and the amide carbon atom of Lasparagine (substrate) is attacked, and a product beta-acyl-enzyme intermediate is generating. In the second reaction step the ester carbon is attacked by a nucleophile which is activated by a water molecule (Cachumba et al., 2016). The principle behind the use of L-asparaginase in the tumours therapy depends upon the fact that tumour cells lack the Asparagine synthetase activity which restricts their ability to synthesis the normally non-essential amino acid L-asparagine. The leukemic cells metabolism depends on the circulating L-asparagine. L-asparaginase action does not affect the normal cells functions which are able to synthesis its own requirements of $\mathrm{L}$-asparagine but it reduces the concentration of the free exogenous circulating L-asparagine and consequently induces the fatal starvation state in the susceptible leukaemic cells which then be destroyed (Ahmed et al., 2015; Alrumman et al., 2019).

L-asparaginase is wide spread enzyme found in many plants, bacteria, and in the serum of certain rodents, but not in man (Emmanuel et al., 2015). Commonly, L-asparaginase produced from microbial sources, because they are easily cultured and Lasparaginase extraction and purification from them is also favourable, and facilitates the production at industrial scale (Ahmad et al., 2012).

Major part of L-asparaginase activity has been predominantly reported in bacterial species like Escherichia coli (Mercado \& Arenas, 1999) Erwina carotovora (Maladkar et al., 1993) and Serratia marcescens (Sukumaran et al., 1979), actinomycetes like Streptomyces venezuelae and S. karnatakensis (Mostafa \& Salama, 1979), yeast includes Saccharomyces cerevisiae (Oliveira

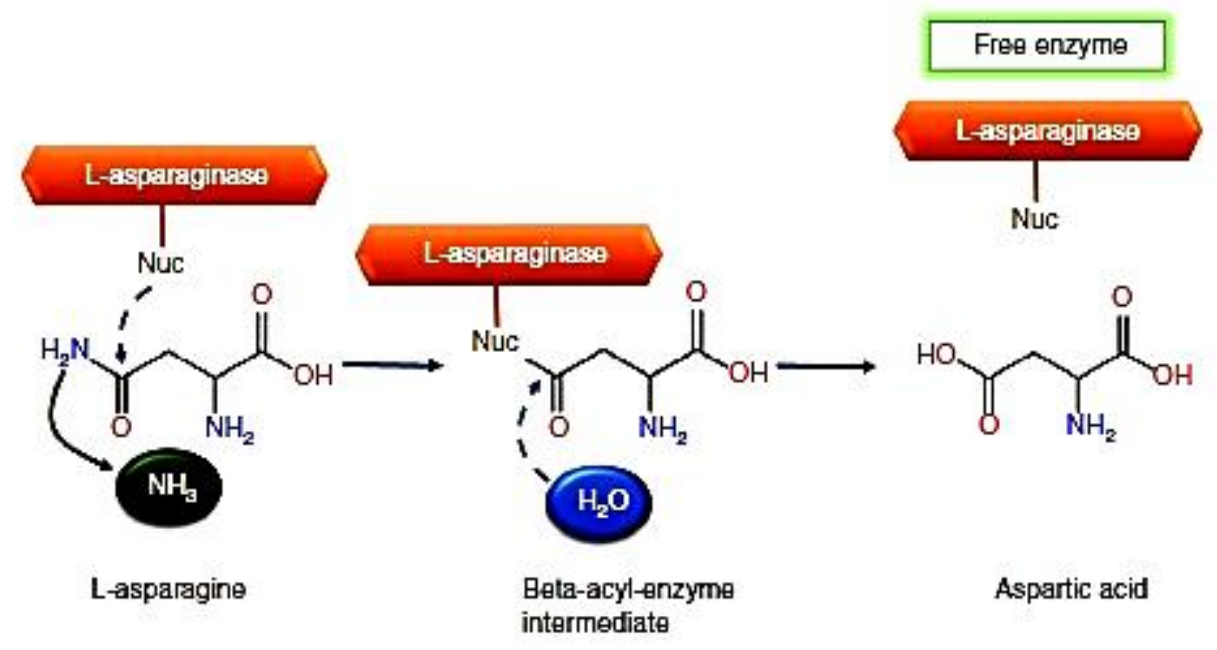

Figure 1 General mechanism of L-asparaginase catalyzed reaction. Dashed arrow is shown by Nucleophilic attack (Cachumba et al., 2016).

Journal of Experimental Biology and Agricultural Sciences

http://www.jebas.org 
et al., 1999) Candida utilis (Kil et al.,1995) while from fungi it has been reported from Aspergillus tamari, A. terreus, and A. niger (Mishra, 2006), and Fusarium sp (Gaddad et al., 2016).

L-Asparaginase from bacterial sources is available now in market which used in the tumours therapy is sold under diverse trade names like Erwinase from Erwinia chrysanthemi and Elspar from Escherichia coli (Manasa \& Nalini, 2014). But it is clear that prokaryotic L-asparaginase has currently reported to cause a lot of side effects upon use in tumour therapy which causes allergic reactions (Patil et al., 2012; Pola et al., 2018; Alrumman et al., 2019). On the otherhands, eukaryotic L-asparaginase derived from yeast and filamentous fungi may induce relatively less toxicity and weak immune response (Asthana \& Azmi 2003; Sarquis et al., 2004). Recently, the use of fungal endophytes as novel new promising L-asparaginase sources is interesting and considered relatively new and there are only few studies which have been reported on it (Chow \& Ting, 2015). The present study focus on the isolation and screening of novel Glutaminase free Lasparaginase producing fungal endophytes from wild medicinal plants associated with antitumour activity.

\section{Materials and Methods}

\subsection{Medicinal plant hosts species collection}

Four medicinal plants viz., Curcuma longa, Murraya koenigii, Catharanthus roseus, and Withania somnifera, traditionally known to be associated with antitumour activity were selected for this study. The plants were collected from different housing gardens of Nanded city, Maharashtra, India during the month of July, 2016. Different healthy plants parts viz., flowers, leaves, stem, rhizomes and roots were collected and placed in polyethylene bags and then stored at $4^{\circ} \mathrm{C}$. The processing of the plant samples was carried out under laboratory condition within $48 \mathrm{~h}$ of its collection.

\subsection{Isolation and identification of fungal endophytes}

The plant parts were first washed with running tap water for 20 minutes. Using a sterile scalpel, the tissues of leaf and flowers were cut into segments with the dimensions of $2 \mathrm{~cm} \times 2 \mathrm{~cm}$ whereas the tissues of stem, rhizomes and roots were cut into a length of $2 \mathrm{~cm}$ each (Chow \& Ting, 2015). Surface sterilization of plants parts was carried out by immersion of the samples for $20 \mathrm{~min}$ in $1.5 \%$ sodium hypochlorite and for $30 \mathrm{~s}$ in $70 \%$ ethanol, and finally rinsed for three times in sterile deionised water to remove traces of the sterilants. The process was repeated triple times on each plant tissues batches (Jan et al., 2013). The sterilized plants segments were injured and placed on Rose Bengal agar medium which was supplemented with $0.05 \mathrm{~g} \mathrm{~L}^{-1}$ of chloramphenicol in order to selection only fungal isolates. Sterilized but non-injured plants segments were used as control and placed on Rose Bengal agar plates where the absence of mycelial growth indicated the plants segments surface effective sterilization whereas mycelial growth presence in the plates seeded with injured tissues was considered as endophytes (Theantana et al., 2007). All the plates were incubated at $30^{\circ} \mathrm{C} / 14$ days. Emerged colonies from injured plants segments were subsequently sub-cultured to Potato Dextrose Agar (PDA) plates to get pure cultures and then maintained in slants at $4^{\circ} \mathrm{C}$ for later investigations. Fungal endophytes with Glutaminase free Lasparaginase producing activity were identified according to their morphological and cultural characteristics.

\subsection{Plate Screening of Glutaminase free L-Asparaginase Production}

In general, it is observed that production of Glutaminase and Lasparaginase is accompanied by an increase acidity of the culture filtrates (Arif \& Hussain, 2014). The plate screening assay was based on Gulati et al. (1997) method in which $\mathrm{pH}$ indicator phenol red (prepared in ethanol) is incorporated in medium containing Glutamine and L-asparagine (sole nitrogen source) for screening the production of glutaminase and L-asparaginase respectively. This method was performed for screening of Glutaminase and L-asparaginase qualitatively. The phenol red is yellow at acidic $\mathrm{pH}$ and turns pink at alkaline $\mathrm{pH}$; hence a pink zone is created around microbial producer colonies and considered as a positive result. Fungal endophytes isolates were screened for L-asparaginase production using Modified Czapek Dox medium (McDox) which is composed of: $(\mathrm{g} / \mathrm{L})$ : $10 \mathrm{~L}-$ asparagine, 2 glucose, $1.52 \mathrm{KH} 2 \mathrm{PO} 4,0.52 \% \mathrm{MgSO} 4.7 \mathrm{H} 2 \mathrm{O}, 0.52$ $\mathrm{KCl}, 0.05 \mathrm{ZnSO} 4.7 \mathrm{H} 2 \mathrm{O}, 0.03 \mathrm{CuNO}$. 3H2O, $0.03 \mathrm{FeSO} 4.7 \mathrm{H} 2 \mathrm{O}$, 20 agar and supplementing the medium with 0.05 phenol red dye and the $\mathrm{pH}$ was adjusted to 6 (Chow \& Ting, 2015). The medium was sterilized at 1.5 atmospheric pressured for 20 minutes. Inoculated plates were incubated at $28^{\circ} \mathrm{C}$ for 5days. Plates containing L-asparagine were examined for pink zones surrounding producers isolates which indicates the positive asparaginase activity, and the isolates were considered as Lasparaginase producing strains (Figure 2). Isolates exhibiting Lasparaginase activity were selected for Glutaminase production screening to select only Glutaminase free L-asparaginase producer strains following same procedure except for L-asparagine which was replaced by Glutamine. Later on, production of Lasparaginase form the Glutamianse free L-asparaginase producing fungal endophytes was estimated quantitatively using Nesslerization method.

\subsection{Nesslerization Method for L- Asparaginase Estimation}

The glutamianse free L-asparaginase producing fungal endophytes isolates were cultured in McDox broth medium and incubated at $28^{\circ} \mathrm{C}$ in shaker incubator set at $120 \mathrm{rpm}$ for 5days. The spore suspension containing $\sim 1 \times 10^{7}$ spores $\mathrm{ml}^{-1}$ was prepared 


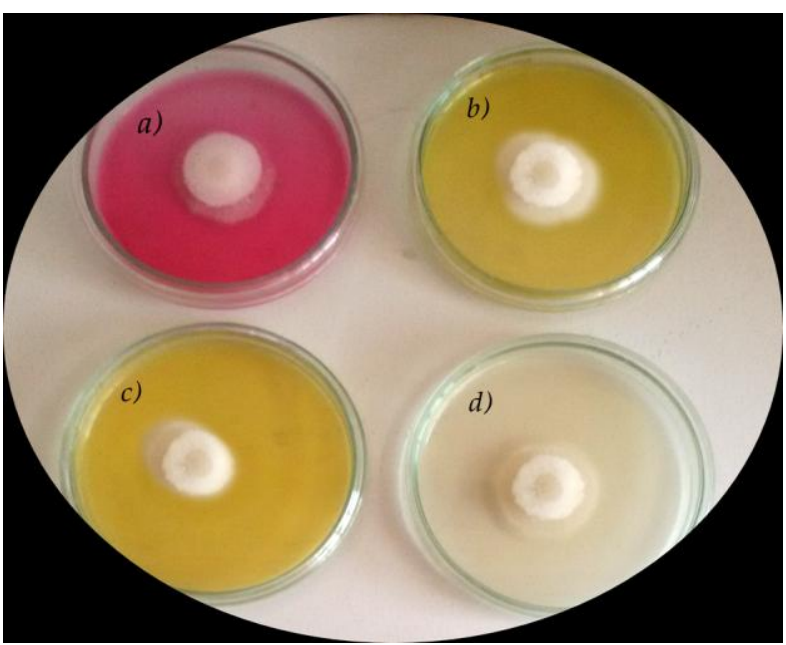

Figure 2 Production of Glutaminase free L-asparaginase by fungal endophyte; Fusarium solani isolated from Curcuma longa rhizome using McDox media. a) containing asparagine and formation of the pink zone was indicating the production of L-asparaginase enzyme, b) containing glutamine and was negative for Glutaminase production, c) control plate without asparagine and glutamine and d) control plate without indicator. Cultures were 3 -day old cultures.

using distilled water containing $0.1 \%$ of Tween- 80 and was used as inoculums. Estimation of L-asparaginase was performed quantitatively by Nesslerization method reported by Imada et al. (1973). In a tube, a prepared mixture was containing $0.5 \mathrm{~mL}$ of $0.05 \mathrm{M} \mathrm{L}$-asparagine, $0.5 \mathrm{~mL}$ of enzyme, $0.5 \mathrm{~mL}$ of $0.5 \mathrm{M}$ Tris- $\mathrm{HCl}$ buffer ( $\mathrm{pH} 8.2$ ), and $0.5 \mathrm{~mL}$ distilled water and this mixture was kept $30 \mathrm{~min}$ at $37^{\circ} \mathrm{C}$. After incubation time, $0.5 \mathrm{~mL}$ of $1.5 \mathrm{M}$ trichloroacetic acid (TCA) was added to the mixture in order to stop the reaction. $0.1 \mathrm{~mL}$ from the reaction mixture was taken into a tube contain $0.2 \mathrm{~mL}$ of Nessler's reagent in $3.7 \mathrm{~mL}$ distilled water and incubated for $20 \mathrm{~min}$. At $450 \mathrm{~nm}$, the optical density was read using UV-Visible spectrophotometer (Kumar et al., 2016). To prepare blank tubes, enzyme was added after the addition of TCA. To get the enzyme activity, standard curve of ammonium chloride gradual concentration was prepared and one international unit (IU) of L-asparaginase was considered as the amount of enzyme which liberates one $\mu \mathrm{mol} \mathrm{min}{ }^{-1} \mathrm{ml}^{-1}$ of ammonia at $37^{\circ} \mathrm{C}$.

\subsection{Protein Estimation}

To calculate the protein specific activity, protein content was quantified following the method described by Bradford (1976) in which the bovine serum albumin was used as a standard.

\subsection{Statistical Analysis}

The experiments were performed in triplicate and the all results are expressed in terms of mean \pm SD. Minitab 18 statistical software was used to perform the statistical analysis.

\section{Results}

\subsection{Isolation of fungal endophytes}

Total seventy eight (78) fungal endophytes were isolated from different plant parts of the four medicinal plants viz., Curcuma longa, Murraya koenigii, Catharanthus roseus and Withania somnifera used. Among the used medicinal plants, high isolating percentage of $60 \%$ was reported from Curcuma longa this was followed by Murraya koenigii (23\%), Catharanthus roseus (14\%) and Withania somnifera (3\%). Hence, Curcuma longa different plant parts may be considered as a good source for fungal endophytes.

\subsection{Plate Screening of Glutaminase free L-Asparaginase Production}

Twenty nine (29) isolates only among the seventy eight (78) fungal endophytes isolates were able to produce L-asparaginase. Five (5) isolates from these 29 isolates were showing production ability of L-asparaginase without Glutaminase activity. Five fungal strains which identified according to morphological characteristics probably were Fusarium solani (from Curcuma longa rhizomes), F. oxysporum (from Murraya koenigii stem ), Aspergilus sp (Murraya koenigii leaves), Penicillium sp (Curcuma longa rhizome), Alternaria sp. (Curcuma longa rhizome). These five isolates were selected for further procedures.

\subsection{Nesslerization Method for L- Asparaginase Estimation}

The enzyme activities were found to occur in the range of 619.102-149.057 $\mathrm{IU} \mathrm{ml}^{-1}$ and a specific activity ranging from 8.807-3.035 IU mg ${ }^{-1}$. F. solani from Curcuma longa rhizomes exhibited high asparaginase activities of $619.102 \mathrm{IU} \mathrm{ml}^{-1}$ with a highest specific activity of $8.807 \mathrm{IU} \mathrm{mg}^{-1}$ as shown in (Table. 1). The experiments were performed in triplicate and the all results are expressed in terms of mean $\pm \mathrm{SD}$.

\section{Discussion and Conclusion}

Fungal endophytes isolated from medicinal plants considered as promising sources of L-asparaginase production with novel characteristics at high therapeutic index. In this study some medicinal plants with antitumour properties has been selected and used for isolation of fungal endophytes which have been screened thoroughly for production of the Glutaminase free L-asparaginase therapeutic enzyme. Results in the present study revealed that fungal endophyte Fusarium solani isolated from Curcuma longa rhizomes showed L-asparaginase activity of $619.102 \mathrm{IU} \mathrm{ml}^{-1}$ which is higher than which previously reported enzyme activities. Similarity, El Refai et al. (2018) and El-Hadi et al. (2017) reported $F$. solani as a potent source of L-asparaginase enzyme with an enzyme activity of $121 \mathrm{U} \mathrm{ml}^{-1}$ and $254 \mathrm{U} \mathrm{ml}^{-1}$ 
Table1 L-asparaginase enzyme activity, protein concentration and specific activity of the Glutaminase free L-asparaginase from isolated fungal endophytes:

\begin{tabular}{|ccccc|}
\hline $\begin{array}{c}\text { S. } \\
\text { No. }\end{array}$ & Fungal Endophytes & Enzyme in IU ml & Protein concentration mg ml & Specific activity IU mg $^{-1}$ \\
\hline 1 & Fusarium solani & $619.102 \pm 1.09$ & $70.296 \pm 0.04$ & $8.807 \pm 0.01$ \\
\hline 2 & Fusarium oxysporum & $514.532 \pm 0.43$ & $69.522 \pm 0.01$ & $7.401 \pm 0.23$ \\
\hline 3 & Penicillium sp. & $307.114 \pm 0.62$ & $61.020 \pm 0.04$ & $5.033 \pm 0.42$ \\
\hline 4 & Aspergillus sp. & $216.847 \pm 0.33$ & $53.221 \pm 0.04$ & $4.920 \pm 0.02$ \\
\hline 5 & Alternaria sp. & $149.057 \pm 0.17$ & $49.113 \pm 0.03$ & $3.035 \pm 0.08$ \\
\hline
\end{tabular}

All results are expressed in terms of mean \pm SD $(n=3)$.

respectively. Gaddad et al. (2016) reported that Fusarium sp. (SMGR-F1) isolated from the papaya leaves produced $111.07 \pm 1.53 \mathrm{IU} \mathrm{ml}^{-1}$ L-asparaginase activity. Sanjotha \& Manawadi (2017) reported production of the enzyme by Aspergillus sp with an activity of $155 \mathrm{U} \mathrm{ml}^{-1}$. Fungal strain C-7 reported by Doriya \& Kumar (2016), was shown L-asparaginase activity of $33.59 \mathrm{U} \mathrm{mL}^{-1}$. Yadav \& Sarkar (2014) have reported that the activity of L-asparaginase from $F$. oxysporum was $182 \mathrm{IU}$ $\mathrm{ml}^{-1}$. Hence findings in the present study reported that Fusarium solani fungal endophyte may be considered as a potential source for production of Glutaminase free L-asparaginase at industrial scale. L-asparaginase enzyme is clinically acceptable in the treatment of tumours especially in the treatment of childhood blood cancers and considered to have exceptional therapeutic properties (Albertsen et al., 2019). Findings of the present study clearly showing that fungal endophytes isolated from medicinal plants which having anti-tumour activities may considered as a better potent alternative source for the Lasparaginase enzyme production which may has a clinically novel properties. These organisms must be taken into consideration through any subsequent future research on Glutaminase free L-asparaginase and may be used in the large scale production. The therapeutic Glutaminase free Lasparaginase enzyme from these organisms may show a higher therapeutic index with fewer side effects according to its novel properties comparing with the enzymes available nowadays in the markets which are from bacterial sources.

\section{Acknowledgments}

The authors would sincerely thank the Director of the School of Life Sciences S. R. T. M. University, Nanded, India for his support and encouragement. This work is a part of the dissertation work in Doctor of Philosophy degree (PhD), by the second author at SRTM University, India.

\section{Conflicts of interest}

We have no conflict of interest to declare.

\section{References}

Ahmad N, Pandit NP, Maheshwari SK (2012) L-asparaginase gene - a therapeutic approach towards drugs for cancer cells. International Journal of Biosciences 2:1-11.

Ahmed MMA, Abo Dahab NF, Taha TM, Hassan FS (2015) Production, Purification and Characterization of L-Asparaginase from Marine Endophytic Aspergillus sp. ALAA-2000 under Submerged and Solid State Fermentation. Journal of Microbial and Biochemical Technology 7:165-172.

Albertsen BK, Grell K, Abrahamsson J, Lund B, Vettenranta K, Jónsson ÓG, Frandsen TL, Wolthers BO, Heyman M, Schmiegelow K (2019) Intermittent Versus Continuous PEGAsparaginase to Reduce Asparaginase-Associated Toxicities: A NOPHO ALL2008 Randomized Study. Journal of Clinical Oncology 37:1638-1646

Alrumman SA, Mostafa YS, Al-izran KA, Alfaifi MY, Taha TH, Elbehairi SE (2019) Production and Anticancer Activity of an LAsparaginase from Bacillus licheniformis Isolated from the Red Sea, Saudi Arabia. Scientific Reports 9: 3756. doi: 10.1038/s41598-019-40512-x

Arif HM, Hussain Z (2014) Important Sources and Medicinal Applications of L-Asparaginase. International Journal of Pharma Research \& Review 3:35-45.

Arjun JK, Aneesh BP, Harikrishnan K (2015) Sequencing and characterization of L-asparaginase (ansB) gene of Bacillus megaterium isolated from Western Ghats, Kerala, India. International Journal of Current Microbiology and Applied Sciences 4:753-760.

Asthana N, Azmi W (2003) Microbial L-asparaginase: a potent antitumour enzyme. Indian Journal of Biotechnology 2:84-194.

Bradford MM (1976) A rapid and sensitive method for the quantitation of microgram quantities of protein utilizing the principle of proteindye binding. Analytical Biochemistry 72:248-254. 
Cachumba JJ, Antunes FA, Peres GF, Brumano LP, Santos JC, Da Silva CC (2016) Current applications and different approaches for microbial 1-asparaginase production. Brazilian Journal of Microbiology 47:77-85.

Chow YY, Ting ASY (2015) Endophytic L-asparaginaseproducing fungi from plants associated with anticancer properties. Journal of Advanced Research 6:869-876.

Doriya K, Kumar DS (2016) Isolation and screening of 1asparaginase free of glutaminase and urease from fungal sp. Biotechnology 6:239. doi: 10.1007/s13205-016-0544-1.

El Refai HA, Zaki RA, Shafei MS, El-Hadi AA, Mostafa H (2018) Evaluation of factors affecting L-asparaginase activity using experimental design. Current Trends in Biotechnology and Pharmacy 12:377-389

El-Hadi AA, El-Refai HA, Shafei MS, Zaki R, Mostafa H (2017) Statistical optimization of L-asparaginase production by using Fusarium solani. Egyptian Pharmaceutical Journal 16:16-23

El-Naggar NE, Moawad H, El-Shweihy NM, El-Ewasy SM (2015) Optimization of Culture Conditions for Production of the Anti-Leukemic Glutaminase Free L-Asparaginase by Newly Isolated Streptomyces olivaceus NEAE-119 Using Response Surface Methodology. BioMed Research International 2015:627031 doi: 10.1155/2015/627031.

Emmanuel E, Nzelibe HC, Onyike E (2015) Isolation, Partial Purification and Characterization of L-Asparaginase from Hedgehog Serum. Journal of Microbial \& Biochemical Technology 7:404-409.

Fouda AH, Hassan S, Eid AM, Ewais E (2015) Biotechnological applications of fungal endophytes associated with medicinal plant Asclepias sinaica (Bioss.). Annals of Agricultural Science 60:95-104.

Gaddad SM, Kumar R, Sedolka VKr, Triveni AG, Kumar MS, Shivannavar CT (2016) Isolation, Screening And Characterization Of L-Asparaginase Producing Fungi From Medicinal Plants. International Journal of Pharmacy and Pharmaceutical Sciences 8:281-283.

Ghasemi A, Asad S, Kabiri M, Dabirmanesh B (2017) Cloning and characterization of Halomonas elongata L-asparaginase, a promising chemotherapeutic agent. Applied Microbiology and Biotechnology 101: 7227-7238.

Gulati R, Saxena RK, Gupta R (1997) A rapid plate assay for screening L-asparaginase producing micro-organisms. Letters in Applied Microbiology 24:23-26.
Imada A, Igarasi S, Nakahama K, Isono M (1973) Asparaginase and glutaminase activities of micro organisms. Journal of General Microbiology 76:85-99.

Jan A, Bhat KM, Bhat SJA, Mir MA, Bhat MA, Wani IA, Rather JA (2013) Surface sterilization method for reducing microbial contamination of field grown strawberry explants intended for in vitro culture. African Journal of Biotechnology 12:5749-5753.

Jha SK, Pasrija D, Sinha RK, Singh HR, Nigam VK, Vidyarthi AS (2012) Microbial L-Asparaginase: A Review On Current Scenario And Future Prospects. International Journal of Pharmaceutical Scinces and Research 3:3076-3090.

Kavya PS, Madhu PC (2019) Isolation and Characterization of LAsparaginase Producing Endophytic Bacteria from Simarouba gluaca. International Journal of Animal Science and Technology 3:1-6.

Kil JO, Kim GN and Park I (1995) Extraction of extracellular Lasparaginase from Candida utilis. Bioscience, Biotechnology, and Biochemistry 59:749-750.

Kumar R, Sedolkar VK, Triveni AG, Kumar MS, Shivannavar CT, Gaddad SM (2016) Isolation, Screening And Characterization Of L-Asparaginase Producing Fungi From Medicinal Plants. International Journal of Pharmacy and Pharmaceutical Sciences 8:281-283.

Maladkar NK, Singh VK, Naik SR (1993) Fermentative production and isolation of L-asparaginase from Erwinia carotovora, EC-113. Hindustan Antibiotics Bulletin 35:77-86.

Manasa C, Nalini MS (2014) L-Asparaginase Activity of Fungal Endophytes from Tabernaemontana heyneana Wall. (Apocynaceae), Endemic to the Western Ghats (India). International Scholarly Research Notices Article 2014: ID 925131, 7 pages, 2014. https://doi.org/10.1155/2014/925131

Mercado L, Arenas G (1999) Escherichia coli L-asparaginase induces phosphorylation of endogenous polypeptides in human immune cells. Sangre 6:438-442.

Mishra A (2006) Production of L-asparaginase, an anticancer agent, from Aspergillus niger using agricultural waste in solid state fermentation. Applied Biochemistry and Biotechnology 135:33-42.

Mostafa SA, Salama MS (1979) L-asparaginase producing Streptomyces from the soil of Kuwait. Zentralbl Bakteriol Naturwiss 134:325-334.

Oliveira EM, Carvajal E, Bon EP (1999) L-Asparaginase II of Saccharomyces cerevisiae. Activity profile during growth using an ure 2 mutant P40-3C and a P40-3C + Ure2p strain. Applied Biochemistry and Biotechnology 311:77-79. 
Patil MP, Patil RH, Mahjeshwari VL (2012) A novel and sensitive agar plug assay for screening of asparagine-producing endophytic fungi from Aegle marmelos. Acta Biologica Szegediensis 56 :175-177.

Pola M, Durthi CP , Rajulapati1 SB, Erva RR (2018) Modelling and optimization of L-Asparaginase production from Bacillus stratosphericus. Current Trends in Biotechnology and Pharmacy 12:390-405

Sanjotha G, Manawadi SI (2017) Isolation, screening, optimization and production of Anti-tumor L-Asparaginase by fungi from Karwar coastal region. Research Journal of Recent Sciences 6:1-7

Sarquis MI, Oliveira EM, Santos AS, Costa GL (2004) Production of L-asparaginase by Filamentous Fungi. Memórias do Instituto
Oswaldo Cruz 99:489-492.

Stierle A, Strobel G, Stierle D (1993) Taxol and taxane production by Taxomyces andreanae, an endophytic fungus of Pacific yew. Science 260:214-216.

Sukumaran CP, Singh DV, Mahadeven PF (1979) Synthesis of Lasparaginase by Serratia marcescens (Nima). Journal of Biosciences 3:263-269.

Theantana T, Hyde KD, Lumyong S (2007) Asparaginase Production By Endophytic Fungi Isolated From Some Thai Medicinal Plants. KMITL Science and Technology Journal 7:13-18.

Yadav N, Sarkar S (2014) Production of L-Asparaginase by Fusarium oxysporum using submerged fermentation. International Journal of Pharmaceutical Science Invention 3:32-40. 